\title{
COMMENTARY
}

\section{The interpretation of brain natriuretic peptide in critical care patients; will it ever be useful?}

\author{
John Dixon ${ }^{1}$ and Barbara Philips ${ }^{2,3 *}$ \\ See related research by Di Somma et al., http://ccforum.com/content/14/3/R116
}

\begin{abstract}
The measurement of B-type natriuretic peptide (BNP) is recommended for the diagnosis of decompensated heart failure, the prognosis of chronic heart failure is worse if BNP is increased and studies suggest that BNP is useful to guide therapy. A study by Di Somma and colleagues adds to the body of evidence showing that patients with a marked decrease in BNP concentrations during their hospital admission are less likely to be readmitted with a further adverse cardiac event than patients in whom BNP fails to decrease. However, the wider interpretation of BNP concentrations in critically ill patients with other conditions remains uncertain.
\end{abstract}

Patients hospitalised for decompensated heart failure (DHF) have a high mortality, are at increased risk of further cardiovascular events, and experience frequent re-admissions to hospital; the accurate identification of high-risk patients before discharge remains a significant clinical challenge. Di Somma and colleagues [1] suggest that changes in B-type natriuretic peptide (BNP) concentration measured at admission, after 24 hours and at discharge may be useful in identifying patients at risk of readmission with a cardiac adverse event after hospitalization for DHF. In their Italian multicentre study, a decrease in BNP concentration of $>25 \% 24$ hours after admission to hospital and a $>46 \%$ decrease at discharge were strong negative prognostic factors for future cardiovascular events. An absolute BNP concentration of $<300 \mathrm{pg} / \mathrm{ml}$ at discharge was also negatively predictive. Combined, the predictive value was improved with a change in BNP concentration of $<46 \%$ at discharge with an absolute BNP concentration of $>300 \mathrm{pg} / \mathrm{ml}$ giving an

\footnotetext{
*Correspondence: bphilips@sgul.ac.uk

IIntensive Care Medicine, Clinical Sciences, Jenner Wing, St George's, University of London, Cranmer Terrace, London SW17 OQT, UK

Full list of author information is available at the end of the article
}

odds ratio for adverse events of 9.61. The authors conclude that high risk patients may benefit from further treatment in hospital for their DHF but they fall short of recommending a treatment regimen and this study does not prove that targeting BNP as a treatment aim would be beneficial. These findings are not unique, but add evidential weight to previous preliminary studies showing poor outcome amongst patients with DHF who fail to decrease their BNP concentrations during their hospital admission [2]

Increased plasma BNP concentration is an independent predictor of cardiovascular events after a diagnosis of heart failure, even after adjusting for traditional risk factors [3]. In the Valsartan Heart Failure Trial (ValHeFT) [4] a higher mortality was observed in stable subjects with chronic heart failure if their BNP concentration measured at the start of the study was $>238 \mathrm{pg} / \mathrm{ml}$, compared with those with a concentration $<41 \mathrm{pg} / \mathrm{ml}$, irrespective of the treatment modality, and in a systematic review [5] of BNP measurements in patients with known heart failure, the relative risk of death was calculated to increase $35 \%$ for every $100 \mathrm{pg} / \mathrm{ml}$ increase in BNP on admission to hospital. Dhaliwal and colleagues [6] studied patients at follow-up clinic after admission for heart failure and patients with either a BNP concentration $<350 \mathrm{pg} / \mathrm{ml}$ or a large percentage decrease of BNP concentration at follow-up had a longer event-free survival.

BNP has a short life and has been shown to decrease in patients with heart failure in response to therapy, thus making it a potential biomarker of treatment [7]. What is less clear is if it is useful as a target for treatment. The Systolic Heart Failure Treatment Supported by BNP (STARS-BNP) trial [8] evaluated BNP-guided care versus standard care in 220 patients admitted with chronic heart failure; no overall difference in mortality was observed, but patients in the BNP-guided group were more likely to have adjustments made to their medications and were less likely to suffer cardiovascular events in the follow-up period (median 15 months).

BNP is a 32 amino acid peptide released by the ventricles, secondary to stretch of the cardiac myocytes. Concentrations of it can change very rapidly and it can 
cause both natriuretic and vasodilatory effects, countering the renin-angiotensin system. Stretch of myocytes is not exclusive to heart failure and, indeed, in critically ill patients many conditions have been shown to increase BNP; for example, sepsis [9], acute lung injury [10], pulmonary embolism [11] and intracerebral haemorrhage [12]. Some distinctions can be made in terms of absolute BNP concentrations observed in different conditions, but the plethora of potential causes of cardiac dysfunction and thus BNP release in patients with complex multiorgan dysfunction has limited the interpretation of BNP concentrations in the critical care setting. Rudiger [9] found that BNP levels in patients with sepsis were similar to those in patients with DHF and that cardiac index and pulmonary artery capillary wedge pressure were more useful in diagnosing DHF. Furthermore, all attempts to correlate BNP concentrations with cardiovascular measurements (for example, pulmonary capillary wedge pressure, left ventricular stroke work index and cardiac index) have shown only weak correlations at best [13].

Forfia and colleagues [13] investigated the relationship between pulmonary capillary wedge pressure and BNP and found only a weak correlation. However, they also observed a strong association between estimated glomerular filtration rate and BNP over and above any evidence of raised filling pressures and concluded that complex interactions must occur between the kidneys and the heart. More recently, Park and colleagues [14] have suggested that BNP is valuable in the assessment and prediction of outcome in cardio-renal syndrome type 4 . It is clear that the interpretation of BNP concentrations in critical care is fraught with difficulty, but in selected patients there are indications that its use may be of value in predicting outcome and perhaps in the future also in guiding therapy

\section{Abbreviations}

$\mathrm{BNP}=\mathrm{B}$-type natriuretic peptide; $\mathrm{DHF}=$ decompensated heart failure.

\section{Competing interests}

The authors declare that they have no competing interests.

\section{Author details}

'General Intensive Care, St George's Hospital NHS Trust, Cranmer Terrace, London SW17 0QT, UK. ${ }^{2}$ Intensive Care Medicine, Clinical Sciences, Jenner Wing, St George's, University of London, Cranmer Terrace, London SW17 OQT, UK. ${ }^{3}$ Department of Clinical Sciences, Cranmer Terrace, London, SW17 ORE, UK.
Published: 6 August 2010

\section{References}

1. Di Somma S, Magrini L, Pittoni V, Marino R, Mastrantuono A, Ferri E, Ballarino P, Semplicini A, Bertazzoni G, Carpinteri G, Mule P, Pazzaglia M, Shah K, Maisel A, Clopton $P$ : In-hospital percentage BNP reduction is highly predictive for adverse events in patients admitted for acute heart failure: the Italian RED Study. Crit Care 2010, 14:R116.

2. Cheng V, Kazanagra R, Garcia A, Lenert L, Krishnaswamy P, Gardetto N, Clopton P, Maisel A: A rapid bedside test for B-type peptide predicts treatment outcomes in patients admitted for decompensated heart failure: a pilot study. J Am Coll Cardiol 2001, 37:386-391.

3. Wang TJ, Larson MG, Levy D, Benjamin EJ, Leip EP, Omland T, Wolf PA, Vasan RS: Plasma natriuretic peptide levels and the risk of cardiovascular events and death. N Engl J Med 2004, 350:655-663.

4. Anand IS, Fisher LD, Chiang YT, Latini R, Masson S, Maggioni AP, Glazer RD, Tognoni G, Cohn JN; Val-HeFT Investigators: Changes in brain natriuretic peptide and norepinephrine over time and mortality and morbidity in the Valsartan Heart Failure Trial (Val-HeFT). Circulation 2003, 107:1278-1283.

5. Doust JA, Pietrzak E, Dobson A, Glasziou P: How well does B-type natriuretic peptide predict death and cardiac events in patients with heart failure: systematic review. BMJ 2005, 330:625.

6. Dhaliwal AS, Deswal A, Pritchett A, Aguilar D, Kar B, Souchek J, Bozkurt B: Reduction in BNP levels with treatment of decompensated heart failure and future clinical events. J Card Fail 2009, 15:293-299.

7. Nohria A, Mielniczuk LM, Stevenson LW: Evaluation and monitoring of patients with acute heart failure syndromes. Am J Cardiol 2005, 96:32G-40G.

8. Jourdain P, Jondeau G, Funck F, Gueffet P, Le Helloco A, Donal E, Aupetit JF, Aumont MC, Galinier M, Eicher JC, Cohen-Solal A, Juillière Y: Plasma brain natriuretic peptide-guided therapy to improve outcome in heart failure: the STARS-BNP Multicenter Study. J Am Coll Cardiol 2007, 49:1733-1739.

9. Rudiger A, Gasser S, Fischler M, Hornemann T, von Eckardstein A, Maggiorini $\mathrm{M}$ : Comparable increase of B-type natriuretic peptide and amino-terminal pro-B-type natriuretic peptide levels in patients with severe sepsis, septic shock, and acute heart failure. Crit Care Med 2006, 34:2140-2144.

10. Rana R, Vlahakis NE, Daniels CE, Jaffe AS, Klee GG, Hubmayr RD, Gajic O: B-type natriuretic peptide in the assessment of acute lung injury and cardiogenic pulmonary edema. Crit Care Med 2006, 34:1941-1946.

11. Lega JC, Lacasse Y, Lakhal L, Provencher S: Natriuretic peptides and troponins in pulmonary embolism: a meta-analysis. Thorax 2009, 64:869-875.

12. James ML, Blessing R, Phillips-Bute BG, Bennett E, Laskowitz DT: S100B and brain natriuretic peptide predict functional neurological outcome after intracerebral haemorrhage. Biomarkers 2009, 14:388-394.

13. Forfia PR, Watkins SP, Rame JE, Stewart KJ, Shapiro EP: Relationship between B-type natriuretic peptides and pulmonary capillary wedge pressure in the intensive care unit. J Am Coll Cardiol 2005, 45:1667-1671.

14. Park S, Cho GY, Kim SG, Hwang YI, Kang HR, Jang SH, Kim DG, Song YR, Bae YA, Jung KS: Brain natriuretic peptide levels have diagnostic and prognostic capability for cardio-renal syndrome type 4 in intensive care unit patients. Crit Care 2009, 13:R70.

\section{doi:10.1186/cc9083}

Cite this article as: Dixon J, Philips B: The interpretation of brain natriuretic peptide in critical care patients; will it ever be useful? Critical Care 2010, 14:184. 